\title{
Commentary \\ Attributable cost of methicillin resistance: an issue that is difficult to evaluate
}

\author{
Jean-François Timsit
}

Groupe d'épidémiologie des cancers et des affections graves INSERM U 578, Service de réanimation médicale, University Hospital Albert Michallon, 38043 Grenoble Cedex, France

Corresponding author: Jean-François Timsit, jftimsit@chu-grenoble.fr

Published: 11 August 2006

This article is online at http://ccforum.com/content/10/4/157

Critical Care 2006, 10:157 (doi:10.1186/cc4994)

(c) 2006 BioMed Central Ltd

See related research by Shorr et al., http://ccforum.com/content/10/3/R97

\begin{abstract}
Estimating the consequences and the cost of methicillin resistance is a difficult challenge. Patients who develop methicillin-resistant ventilator-associated pneumonia (VAP) are very different from those who develop methicillin-sensitive VAP, and biased estimates are frequent. We reviewed some important confounding factors of which the reader should be aware.
\end{abstract}

In the previous issue of Critical Care, Shorr and coworkers [1] provided new data on the morbidity and cost burden attributable to methicillin-resistant Staphylococcus aureus (MRSA)-associated early-onset pneumonia (EOP). Based on the data recorded by 42 US hospitals, those investigators found methicillin resistance to be associated with a significant 4- to 6-day excess in mechanical ventilation, and intensive care unit (ICU) and in-hospital days. It was associated with a nonsignificant increase of about US $\$ 8000$ in total costs, after controlling for case mix and severity. The authors made particular effort to select monomicrobial pneumonias and to adjust the calculations based on underlying illness, and on the severity and duration of ICU stay before EOP. However, this estimated increase in costs should be regarded with caution because of a number of potential biases associated with this type of analysis.

First, the observed incidence of EOP was very low. The overall risk for ventilator-associated pneumonia (VAP) is between $9.7 \%$ and $22.8 \%$ [2]. EOP represents at least onethird of cases. Consequently, the rate of EOP should be higher than 3.2\% [3]. Because Shorr and coworkers found that only 499 episodes were recorded in 42 hospitals over 2 years, this suggests that the incidence was unusually low or that EOP was largely under-reported. This could have introduced bias because unrecognized episodes might be different (probably less severe) than reported ones. Any under-recognition of EOP might have resulted from the known lack of reproducibility of ICD-9 (International Classification of Diseases, ninth edition) [4]. Moreover, MRSA VAP has been reported to occur mainly late in the ICU stay [5-8]; MRSA represents fewer than 5\% of microorganisms encountered in EOP episodes [9]. The factors that impact on outcomes of EOP may be different from those in late-onset pneumonia $[9,10]$. For example, EOP is associated a shorter ICU stay, with significantly fewer days of mechanical ventilation, of central vein catheterization and of use of ICU resources [9]. This fact probably largely explained why the ICU length of stay (4 days) was considerably lower in the report by Shorr and coworkers than in the recent report by Combes and coworkers (i.e. 11 days) [5].

Second, MRSA and methicillin-sensitive Staphylococcus aureus (MSSA) EOP were not matched for the same hospital, and therefore variability in charges between hospitals could account for some of the observed differences. Surprisingly, the authors found that the ICU resources and extra costs related to MRSA EOP were higher only for survivors, as opposed to MSSA EOP. On the contrary, deaths occurred earlier in fatal MRSA EOP, leading to lower hospital costs for nonsurvivors. Because MRSA VAP has not been associated with higher rates of organ dysfunction than MSSA VAP [5], the potential causes of this finding are speculative (e.g. differences in the rate of do-not-resuscitate orders, differences in case mix, differences in the adequacy of antimicrobial treatment, or chance) and might have had a confounding impact on the final result.

Despite these limitations, economic studies such as that conducted by Shorr and coworkers [1] provided further

EOP = early-onset pneumonia; ICU = intensive care unit; MRSA = methicillin-resistant Staphylococcus aureus; MSSA = methicillin-sensitive Staphylococcus aureus; VAP $=$ ventilator-associated pneumonia. 
evidence of the cost of MRSA infections and provide new arguments for funding the fight against MRSA spread in the ICU.

\section{Competing interests}

The author declares that they have no competing interests.

\section{References}

1. Shorr AF, Tabak YP, Gupta V, Johannes R, Liu LZ, Kollef MH: Morbidity and cost burden of methicillin-resistant Staphylococcus aureus in early onset ventilator-associated pneumonia. Crit Care 2006, 10:R97.

2. Safdar N, Dezfulian C, Collard HR, Saint S: Clinical and economic consequences of ventilator-associated pneumonia: a systematic review. Crit Care Med 2005, 33:2184-2193.

3. Bornstain C, Azoulay E, De Lassence A, Cohen Y, Costa MA, Mourvillier B, Descorps-Declere A, Garrouste-Orgeas M, Thuong M, Schlemmer B, et al.: Sedation, sucralfate, and antibiotic use are potential means for protection against early-onset ventilator-associated pneumonia. Clin Infect Dis 2004, 38:14011408.

4. McCarthy EP, lezzoni LI, Davis RB, Palmer RH, Cahalane M, Hamel MB, Mukamal K, Phillips RS, Davies DT Jr: Does clinical evidence support ICD-9-CM diagnosis coding of complications? Med Care 2000, 38:868-876.

5. Combes A, Luyt CE, Fagon JY, Wollf M, Trouillet JL, Gibert C, Chastre J; PNEUMA Trial Group: Impact of methicillin resistance on outcome of Staphylococcus aureus ventilator-associated pneumonia. Am J Respir Crit Care Med 2004, 170: 786-792.

6. Zahar JR, Clec'h C, Tafflet M, Garrouste-Orgeas M, Jamali S, Mourvillier B, De Lassence A, Descorps-Declere A, Adrie C, Costa de Beauregard MA, et al.: Is methicillin resistance associated with a worse prognosis in Staphylococcus aureus ventilator-associated pneumonia? Clin Infect Dis 2005, 41: 1224-1231.

7. Pujol M, Corbella X, Pena C, Pallares R, Dorca J, Verdaguer $R$, Diaz-Prieto A, Ariza J, Gudiol F: Clinical and epidemiological findings in mechanically-ventilated patients with methicillinresistant Staphylococcus aureus pneumonia. Eur J Clin Microbiol Infect Dis 1998, 17:622-628.

8. Rello J, Torres A, Ricart M, Valles J, Gonzalez J, Artigas A, Rodriguez-Roisin R: Ventilator-associated pneumonia by Staphylococcus aureus. Comparison of methicillin-resistant and methicillin-sensitive episodes. Am J Respir Crit Care Med 1994, 150:1545-1549.

9. Ibrahim $\mathrm{EH}$, Ward S, Sherman G, Kollef $\mathrm{MH}$ : A comparative analysis of patients with early-onset vs late-onset nosocomial pneumonia in the ICU setting. Chest 2000, 117:1434-1342.

10. Moine P, Timsit JF, De Lassence A, Troche G, Fosse JP, Alberti C, Cohen Y; OUTCOMEREA study group: Mortality associated with late-onset pneumonia in the intensive care unit: results of a multi-center cohort study. Intensive Care Med 2002, 28: 154-163. 